\title{
REDESAIN TERMINAL BIS KEDAMIN
}

\author{
Anfasa Teguh Wardhana ${ }^{1}$, Jawas Dwijo Putro², Muhammad Ridha Alhamdani \\ ${ }^{1}$ Mahasiswa, Program Studi Arsitektur, Fakultas Teknik, Universitas Tanjungpura \\ Anfasa4417@gmail.com \\ ${ }^{2}$ Program Studi Arsitektur, Fakultas Teknik, Universitas Tanjungpura \\ ${ }^{3}$ Program Studi Arsitektur, Fakultas Teknik, Universitas Tanjungpura
}

Naskah diajukan pada: 18 Februari 2021

Naskah revisi akhir diterima pada: 21 Februari 2021

\begin{abstract}
Abstrak
Transportasi merupakan aktivitas perpindahan suatu individu atau kelompok dan alat atau barang dari suatu tempat ke tempat lain. Terdapat 3 macam jenis transportasi: darat, air dan udara. Transportasi berdasarkan jenisnya dikelompokkan menjadi transportasi pribadi dan transportasi umum. Di Kapuas Hulu terdapat 6 Terminal Bis salah satunya Terminal Bis Tipe B yang berada di Kedamin yang merupakan terminal bis dengan tipe paling tinggi di Kapuas Hulu. Untuk Terminal Bis Tipe B. Terminal Kedamin belum memenuhi syarat yang ditetapkan dalam peraturan pemerintah sehingga perlu dilakukan Redesainuntuk memenuhi standar terminal Tipe B. Terminal bis yang terlihat kumuh dikarenakan aktivitas bongkar muat tidak pada tempatnya sehingga mengganggu kenyamanan pengunjung terminal bis. Fasilitas penunjang aktivitas pengelola bis tidak memadai. Area tempat tunggu kedatangan dan keberangkatan yang tidak mencukupi. Aktivitas dalam terminbal tidak teratur sehingga mengganggu sirkulasi kendaraan, maka dari itu dibutuhkan Redesain pada Terminal Bis Kedamin ini. Perancangan Terminal Bis menerapkan konsep kontekstual untuk menyesuaikan kondisi bangunan didalam site dengan kondisi sekitar.
\end{abstract}

Kata-kata Kunci: Terminal Bis, Kedamin, Kapuas Hulu, Redesain, Pendekatan Kontekstual

\begin{abstract}
Transportation is the activity of moving an individual or group and tools or goods from one place to another. There are 3 types of transportation: land, water and air. Transportation by type is grouped into private transportation and public transportation. In Kapuas Hulu there are 6 Bus Terminals, one of which is the Type B Bus Terminal in Kedamin which is the highest type bus terminal in Kapuas Hulu. For the Type B Bus Terminal, the Kedamin Terminal has not met the requirements stipulated in government regulations, so it is necessary to redesign it to meet the standard for the Type B terminal. Bus terminals that look dirty are due to the unloading and loading activities that are not in place so that it disturbs the comfort of bus terminal visitors. Supporting facilities for bus management activities is inadequate. Insufficient arrival and departure waiting areas. Activities on a regular basis are disrupting the circulation of vehicles, therefore it is necessary to redesign the Kedamin Bus Terminal. The Bus Terminal design applies a contextual concept to adapt the conditions of the building on site to the surrounding conditions.
\end{abstract}

Keywords: Bus Station, Kedamin, Kapuas Hulu, Redesign, Contextual Approach

\section{Pendahuluan}

Menurut Morlok (2005), transportasi merupakan aktivitas perpindahan maupun bongkar muat. Transportasi manusia dan barang bukan tujuan akhir karena permintaan. Permintaan transportasi akan ada jika terdapat fakor faktor pendorongnya. Transportasi bermanfaat bagi ekonomi, sosial, politis dan kewilayahan. Transportasi terbagi menjadi tiga moda yaitu darat, udara, dan air. Kelebihan transportasi darat fleksibel dalam pelayanan karena mudah untuk mengubah arah dan haluan.

Terminal yang ada di Kapuas Hulu tahun 2019 sebanyak 6 terminal bertambah 4 unit dibanding tahun 2010. Dengan penambahan tersebut, berarti saat ini fasilitas terminal angkutan darat 
sudah dapat ditemukan di Kecamatan Badau, Batang Lupar, Semitau dan Kecamatan Suhaid selain di kedua kecamatan yang telah disebutkan sebelumnya (RPJMD Kabupaten Kapuas Hulu tahun 2015 tentang Gambaran Umum Kondisi Daerah).

Terminal bis Kedamin merupakan terminal tipe B, yang dibangun pada tahun 2000, dan mengalami renovasi pada tahun 2007 akan tetapi tidak terlihat adanya perubahan pada Terminal Kedamin ini, sehingga kondisinya menjadi terbengkalai, kondisinya dapat dilihat pada Gambar 1. Keadaan terminal yang dianggap kumuh dan tidak layak sebagai tempat pemberhentian menjadi keluhan terbesar masyarakat pengguna transportasi darat di Kapuas Hulu.

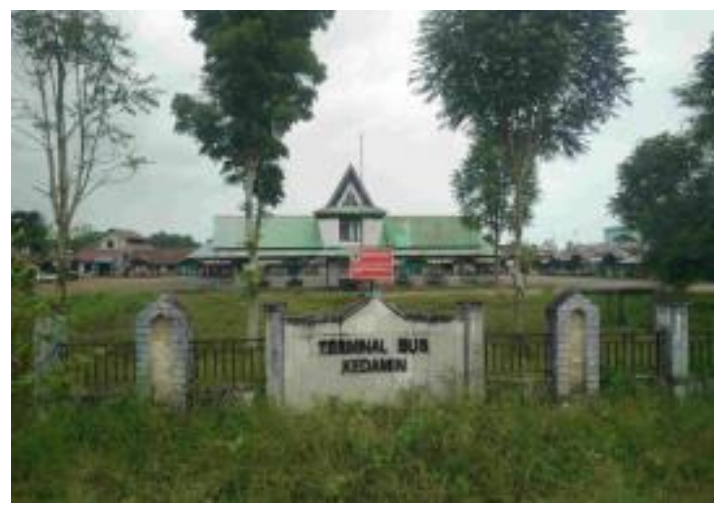

Gambar 1. Terminal Bis Kedamin Sumber: Penulis, 2020

Selain kondisi eksisting yang menjadi keluhan masyarakat, fasilitas yang terdapat di Terminal ini juga tidak diperhatikan sehingga untuk memenuhi persyaratan terminal dengan Tipe B tidak terpenuhi. Lihat Gambar 2.

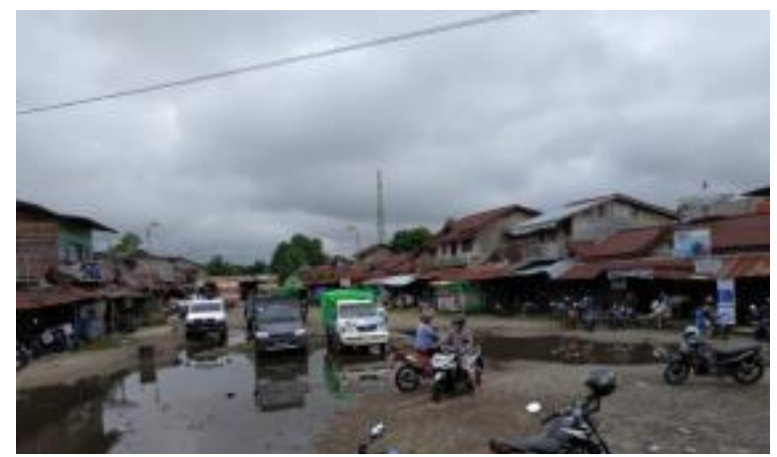

Gambar 2. Kondisi Eksisting Terminal Bis Kedamin Sumber: Penulis, 2020

Redesain Terminal Kedamin dilakukan untuk menyesuaikan standar yang ada pada indikator terminal Tipe B. Perancangan Terminal Kedamin menyesuaikan dengan lokasi dan konteks lokasi akan dibangunnya Terminal ini. Penyesuaian dengan lokasi agar dapat menghargai bangunan sekitar. Konsep kontekstual melibatkan hubungan bangunan dengan lingkungan. Seperti hubungan bangunan dengan tapak.

Kontekstual dalam arsitektur terdapat dua kelompok, yaitu kontras dan harmonis. Penerapan kontekstual dalam perancangan Terminal Bis Kedamin ini menggunakan kontekstual yang harmoni. Penggunaan kontekstual harmoni bertujuan untuk menyelaraskan Terminal Bis Kedamin dengan bangunan yang ada di sekitar. Menyesuaikan dengan budaya yang berada di lokasi Terminal. 
Menyesuaikan dengan kebutuhan aktivitas yang ada di Terminal, baik itu untuk pengelola dan pengunjung Terminal Bis.

\section{Kajian Pustaka}

Menurut American Heritage Dictionary (2000) "Redesign mean to make a revision in the appearance or function of", yang dapat diartikan membuat revisi dalam penampilan atau fungsi.

Terminal adalah prasarana perangkutan jalan untuk keperluan menurunkan dan menaikkan penumpang atau barang, perpindahan intra atau antarmoda angkutan, serta mengatur kedatangan dan pemberangkatan kendaraan umum (Warpani, 2002: 71).

Tabel 1. Tabel Persyaratan Letak dan Luas Terminal

\begin{tabular}{|c|c|c|c|}
\hline & Tipe A & Tipe B & Tipe c \\
\hline Letak & $\begin{array}{l}\text { - Dalam jaringan } \\
\text { trayek } \\
\text { antarkotaantarpr } \\
\text { opinsi. } \\
\text { - Di jalan arteri } \\
\text { dengan kelas } \\
\text { minm.III.A. }\end{array}$ & $\begin{array}{l}\text { - Dalam jaringan trayek } \\
\text { antarkota } \\
\text { propinsi. } \\
\text {-Di jalan arteri atau } \\
\text { kolektor dengan kelas } \\
\text { minimal III.B. }\end{array}$ & $\begin{array}{ll}\text { - Dalam wilayah } \\
\text { DT.II } \\
\text { - } \quad \text { Dalam jaringan } \\
\text { - } \quad \text { Trayek } \\
\text { pedesaan } \\
\text { - Di } & \text { jalan } \\
\text { kolektor atau } & \text { lokal } \\
\text { dengan } & \text { kelas } \\
\text { minimal III.A } & \end{array}$ \\
\hline $\begin{array}{l}\text { Luas lahan } \\
\text { minimal (Ha) }\end{array}$ & $\begin{array}{l}\text { 5Ha di P.Sumatera \& } \\
\text { P.Jawa 3Ha di P.Lain }\end{array}$ & $\begin{array}{l}\text { 3Ha di P.Sumatera \& } \\
\text { P.Jawa 2Ha di P.Lain }\end{array}$ & $\begin{array}{l}\text { Sesuai dengan } \\
\text { permintaan akan } \\
\text { angkutan }\end{array}$ \\
\hline $\begin{array}{l}\text { Jarak antar } \\
\text { terminal sekelas } \\
\text { minimal }(\mathrm{Km})\end{array}$ & $\begin{array}{l}\text { 20km di P.Jawa } \\
\text { 30km di P.Sumatera } \\
\text { 50km di P.Lain }\end{array}$ & $\begin{array}{l}\text { 15km di P.Jawa } \\
\text { 30km di P.lain }\end{array}$ & \\
\hline $\begin{array}{l}\text { Jarak minimal } \\
\text { akses jalan } \\
\text { masuk/keluar } \\
\text { ke/dari terminal } \\
\text { (M) }\end{array}$ & 100m di P.Jawa & $\begin{array}{l}\text { 30m di P.lain } \\
\text { Dihitung dari jalan ke } \\
\text { pintu keluar atau masuk } \\
\text { terminal }\end{array}$ & $\begin{array}{l}\text { Sesuai dengan kebutuhan } \\
\text { untuk kelancaran } \\
\text { lalulintas di sekitar } \\
\text { terminal. }\end{array}$ \\
\hline
\end{tabular}

Sumber: Keputusan Menteri Perhubungan RI No.13 Tahun 1995

Aktivitas terminal dikelompokkan dua zona, yaitu zona sirkulasi dan zona penunjang. Pengelompokkan ini memberikan kelancaran dan efisiensi gerak. Masing-masing zona memiliki fungsi tersendiri, yaitu :

A. Zona sirkulasi:

- Tempat memuat penumpang dan/atau barang

- Tempat perpindahan moda

- Tempat istirahat dan pemeliharaan kendaraan

B. Zona penunjang berfungsi sebagai:

- Tempat menunggu bagi penumpang

- Tempat pelayanan dokumentasi

- Tempat istirahat 


\section{Metode}

Pada perancangan gedung ini menggunakan metode Pendekatan Kontekstual harmonis yang menunjukan hubungan antara bangunan dengan lingkungan sekitar. Arsitektur kontekstual memperlihatkan hubungan yang harmonis antara bangunan secara individu dengan lingkungan. Tujuan dari Arsitektur kontekstual adalah menjaga atau memanfaatkan keindahan/potensi alam letak keberadaannya (site) dan nilai nilai lokal sekitarnya.

Analisis internal merupakan analisis kebutuhan ruang. Untuk mendapatkan ruang-ruang yang dibutuhkan pada perancangan Redesain Terminal Bis Kedamin, maka perlu melihat pelaku dan kegiatan. Setelah kebutuhan ruang diperoleh, tahap selanjutnya yaitu menentukan besaran ruang yang dibutuhkan oleh setiap ruang. Skema analisis internal pada Terminal Bis Kedamin dapat dilihat pada gambar

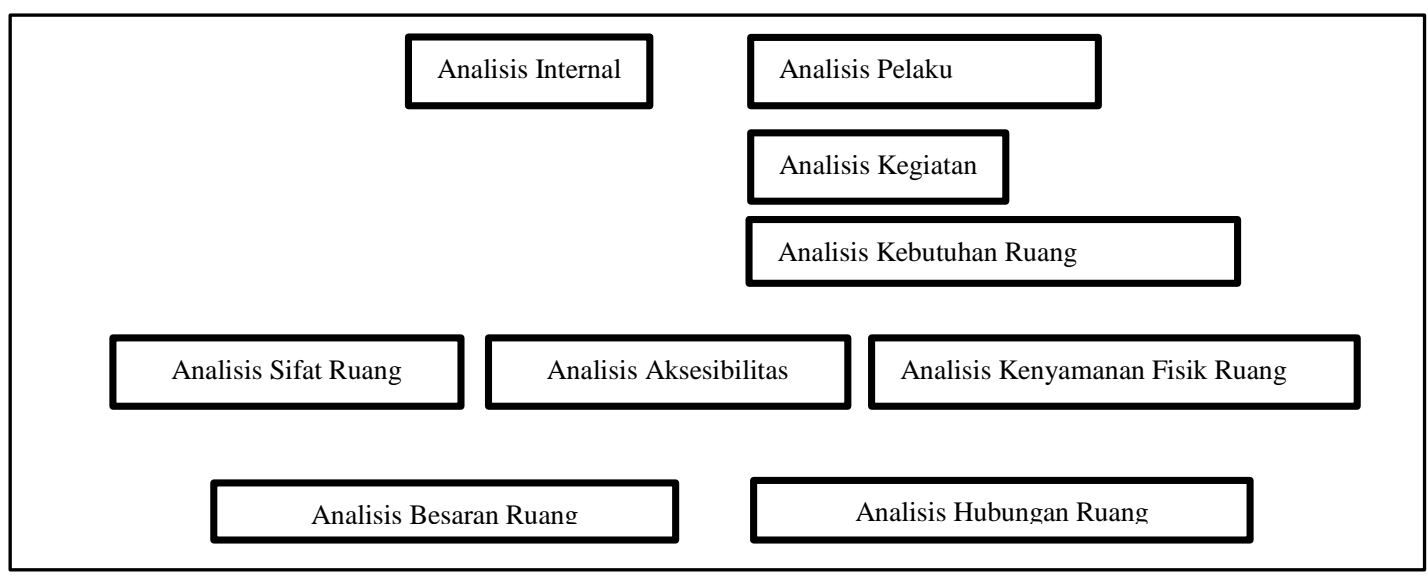

Gambar 3. Skema analisis Internal Terminal Bis Kedamin Sumber: Penulis, 2020

Pengumpulan data melalui observasi langsung Menganalisis hasil dengan mengkomparisasikan data yang telah didapat yang berkaitan dengan Terminal Bis Kedamin. Data yang dianalisis mulai dari ruang yang dibutuhkan dan fungsi pada bangunan tersebut dilanjutkan dengan menganalisis struktur dan utilitas bangunan, menganalisis tapak lingkungan beserta arsitektur lingkungan untuk mendapatkan orientasi dan perletakan bangunan, sistem penghawaan, pencahayaan dan lain-lain. Dilanjutkan dengan Tahap konsep yaitu konsep perancangan berdasarkan analisis yang telah dilakukan. Kemudian tahap prarancangan.

\section{Hasil dan Pembahasan}

\section{Lokasi Perancangan}

Lokasi perancangan berada di Kedamin Hulu, Putussibau Selatan Kabupaten Kapuas Hulu. Luas lahan tersebut adalah $15.600 \mathrm{~m} 2$ (1,56 hektar). Lokasi ini dapat dicapai melalui jalur darat. Kabupaten Kapuas Hulu dibentuk berdasarkan Undang-Undang Nomor 3 Tahun 1953 dengan luas wilayah 29.842,00 km2 atau 2.984.200 Ha, Letak Geografis Kedamin Kecamatan Putussibau Selatan $0^{\circ} 15^{\prime}-1^{\circ} 25^{\prime}$ Bujur Timur, dan $111^{\circ} 39^{\prime}-114^{\circ} 13^{\prime}$ Lintang Utara.

Batas administratif kabupaten Kapuas Hulu: Sebelah utara dengan Sarawak (Malaysia Timur), Sebelah Barat dengan Kabupaten Sintang, Sebelah Selatan dengan Kabupaten Sintang, Sebelah Timur dengan Kalimantan Timur dan Kalimantan Tengah, luas wilayah. Umumnya beriklim tropis dengan temperatur udara rata-rata perbulan berkisar antara $22,9^{\circ} \mathrm{C}$ sampai $33,5^{\circ} \mathrm{C}$. Intensitaspenyinaran matahari adalah 38\%. Curah hujan yang cukup tertinggi terjadi pada Mei (547,6 $\mathrm{mm}$ ) dan curah hujan yang rendah antara bulan Agustus (222,2 mm). 


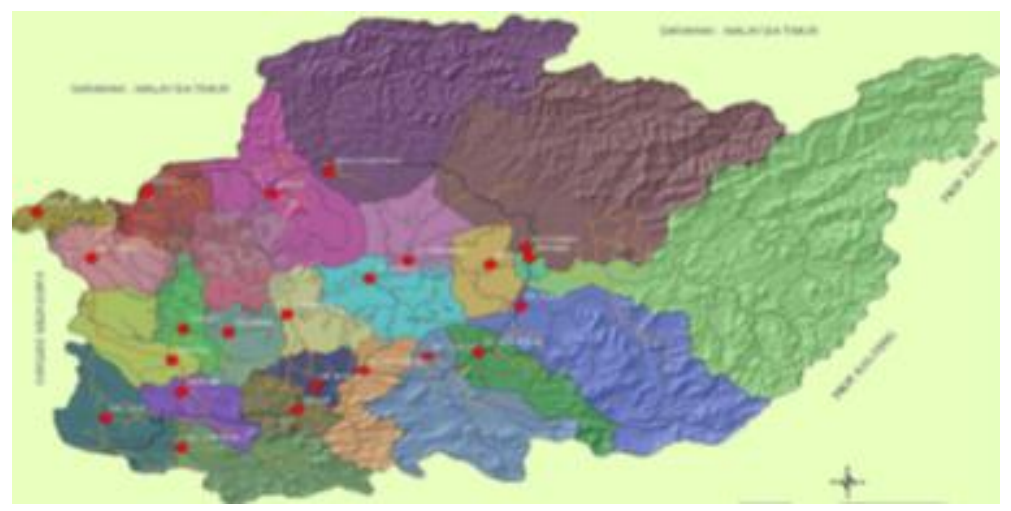

Gambar 4. Peta Kabupaten Kapuas Hulu

Sumber: RPJMD Kabupaten Kapuas Hulu, 2015

\section{Landasan Konseptual}

Landasan Konseptual, merupakan proses analisa konsep internal dan eskternal dari perancangan Terminal Bis Kedamin yang mana nantinya akan ditrerapkan didalam desain.

Kegiatan dalam Terminal Bis Kedamin dikelompokan berdasarkan Zona Pelayanan Terminal Bis Tipe B menurut Peraturan Menteri Perhubungan Republik Indonesia Nomor PM 132 Tahun 2015 tentang Penyelenggaraan Terminal Penumpang Angkutan Jalan. Pengelompokan Zona dibagi mejadi beberapa bagian yaitu Zona Penumpang sudah bertiket atau Zona I, Zona Penumpang belum bertiket atau Zona II, Zona Perpindahan merupakan tempat perpindahan penumpang dari berbagai angkutan atau transportasi, Zona Pengendapan merupakan tempat bagi Angkutan umum setelah menurunkan penumpang. Lebih detailnya dilihat pada gambar.

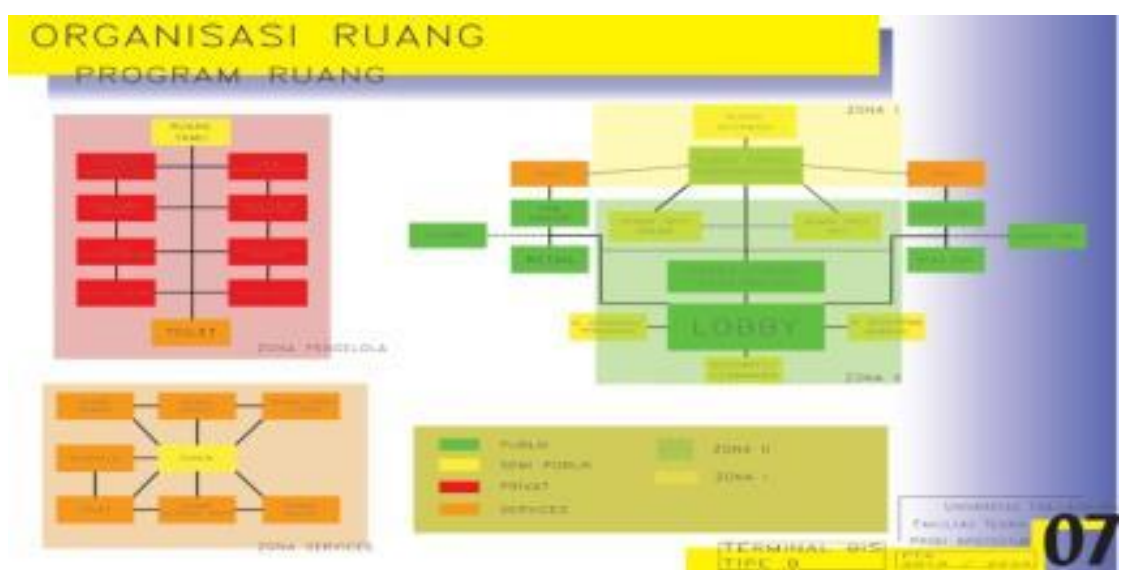

Gambar 5. Pengelompokan Zona Pelayanan Terminal Bis Tipe B

Sumber: Penulis, 2020

Faktor ekternal seperti tapak, iklim, dan kebijakan daerah yang kemudian diterapkan kedalam desain ruang luar bangunan.

Dari analisis sirkulasi yang telah dilakukan, maka hasil analisis sirkulasi yaitu Sirkulasi utama menuju site dapat diakses melalui Jalan Lintas Selatan Kedamin. Jalan tersebut menggunakan perkerasan aspal dan memiliki 2 arah kendaraan.

Analisis perletakan yang telah dilakukan, perletakan bangunan dan terminal berada di tengah site yang menjauhi atau memberi jarak pada bangunan terhadap J1. Lintas Selatan Kedamin Hulu untuk meminimalisir kebisingan yang diterima dalam bangunan serta memberi space sirkulasi kendaraan.

Analisis orientasi dilakukan berdasarkan data tapak yaitu iklim, view kelaur site, dan kebisingan. Berdasarkan hal tersebut, maka orientasi bangunan terminal bis Kedamin menghadap 
barat kearah Jl. Lintas Selatan Kedamin Hulu untuk mempermudah entrance bangunan bagi pengunjung.

Analisis bentuk berdasarkan bentuk-bentuk ruang dasar yang memiliki kondisi khusus disetiap fungsi. Analisis gubahan bentuk dilakukan untuk dapat mendukung kegiatan Perancangan Redesain Terminal Bis. Bentukan dasar dari bangunan yaitu berbentuk persegi empat dan mengalami perubahan bentuk mengikuti konsep bangunan sebagai bangunan terminal.

Pada bentuk bangunan untuk menciptakan bentuk atap dan pembagian zona. Bentuk persegi memanjang pada bagian tengah merupakan bangunan terminal keberangkatan, atap bangunan dibuat setengah pelana untuk memaksimalkan masuknya cahaya matahari ke dalam bangunan. Pada belakang bangunan mengalami pengurangan bentuk mengikuti arah bentuk site untuk mempermudah arah sirkulasi kendaraan dengan site yang cukup sempit.

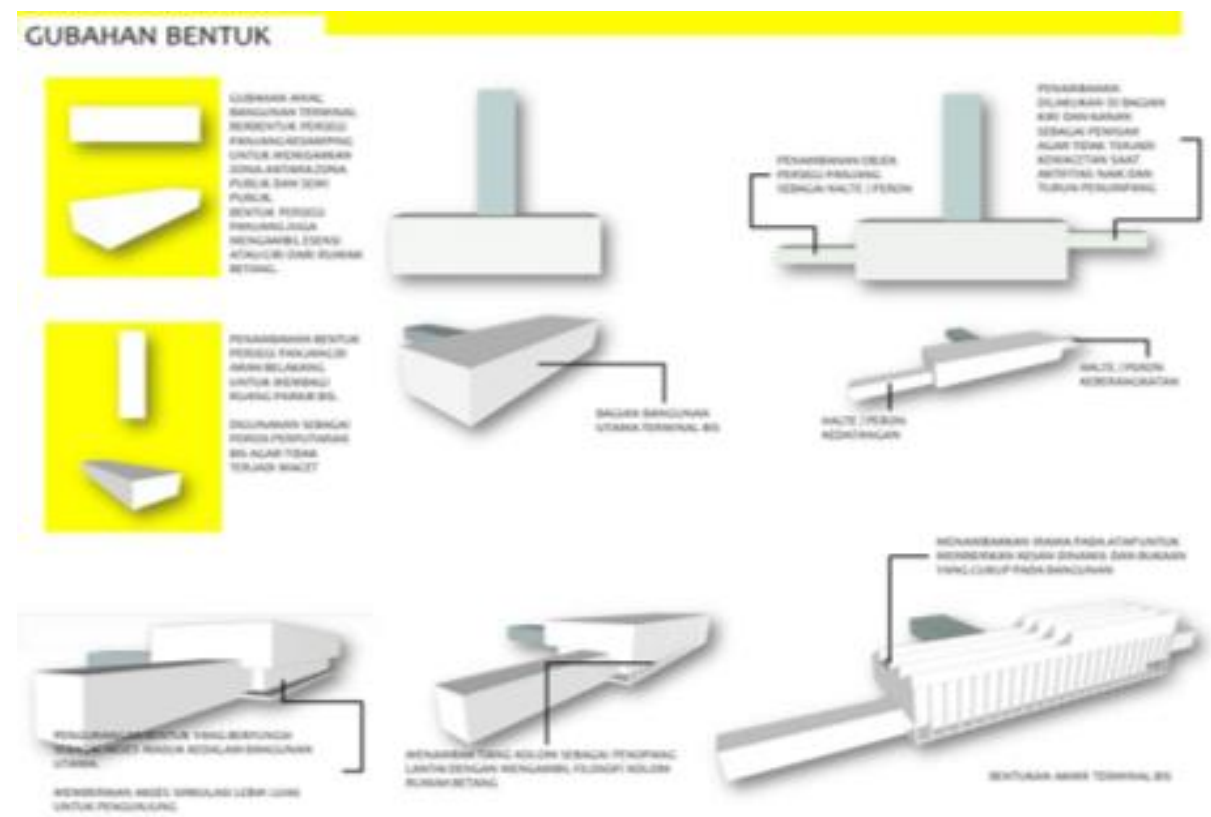

Gambar 6. Analisis Gubahan Bentuk

Sumber: Penulis, 2020

Analisis utilitas mengenai penentuan sistem jaringan utilitas dalam bangunan. Jaringan utilitas merupakan jaringan pelengkap bagi suatu bangunan

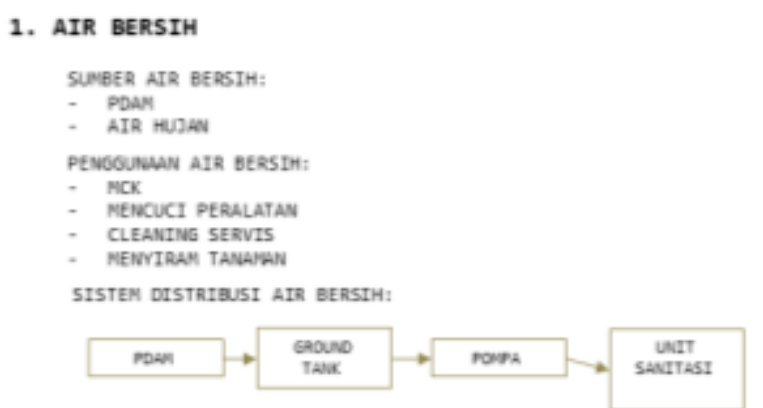

Gambar 7. Sistem Air Bersih

Sumber: Penulis, 2020

Tata udara menggunakan AC central pada gedung pengelola yang luas dan pada ruang tunggu pengunjung. Penggunaan kipas angin digunakan pada ruang kerja pengelola. 


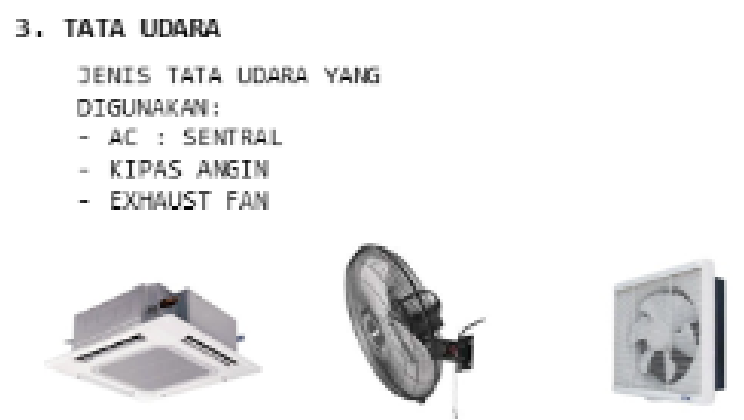

Gambar 8. Sistem HVAC Bangunan Terminal Bis Kedamin Sumber: Penulis, 2020

Sumber listrik berasal dari PLN dan genset sebagai sumber alternatif jika terjadi gangguan dari sumber listrik PLN.

Analisis struktur menggunakan sistem struktur bentang kecil. Adapun penjelasan mengenai analisis struktur dapat dilihat pada gambar.

Bangunan menggunakan bentang 6 meter untuk tiap kolom dan pada bangunan menggunakan sistem pondasi tiang pancang, struktur bentang menggunakan beton bertulang, atap menggunakan dak beton dan penggunaan plafond dengan bahan gypsum.

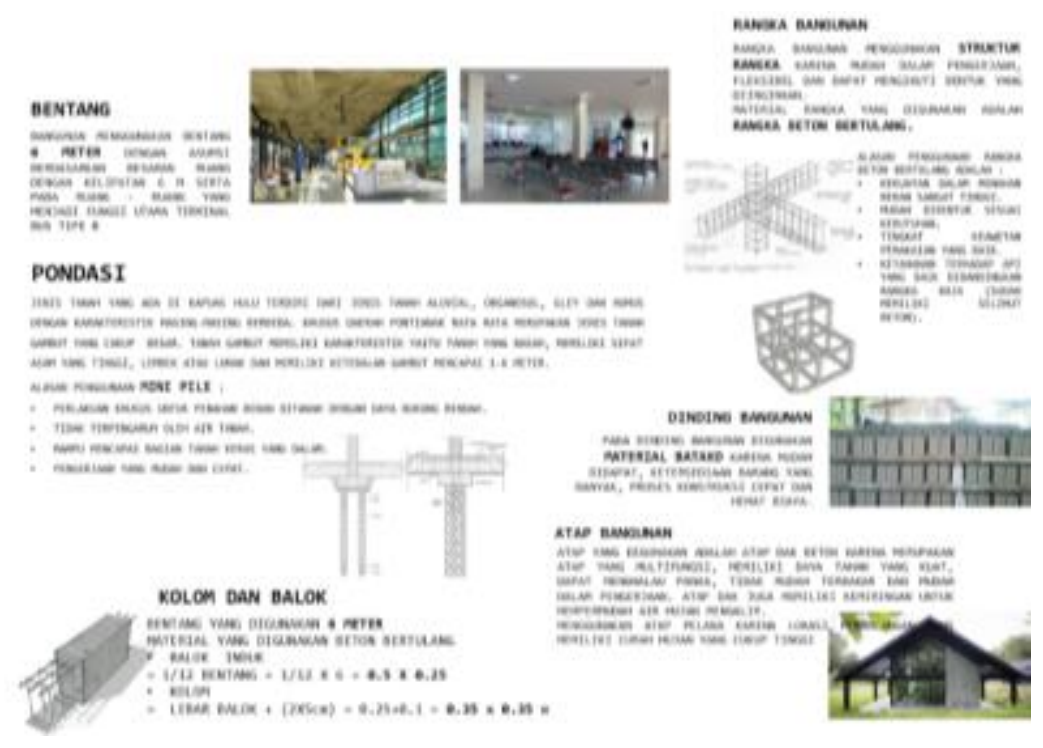

Gambar 9. Analisis Struktur Bangunan Terminal Bis Kedamin

Sumber: Penulis, 2020

\section{Hasil}

Terminal Bis Kedamin meiliki satu jalur masuk utama dan satu jalur keluar kearah Jl.Lintas Selatan Kedamin Hulu. Akses pada kawasan terbagi menjadi 2 jenis berdasarkan kendaraan maupun pejalan kaki, yaitu akses publik dan semi publik. 


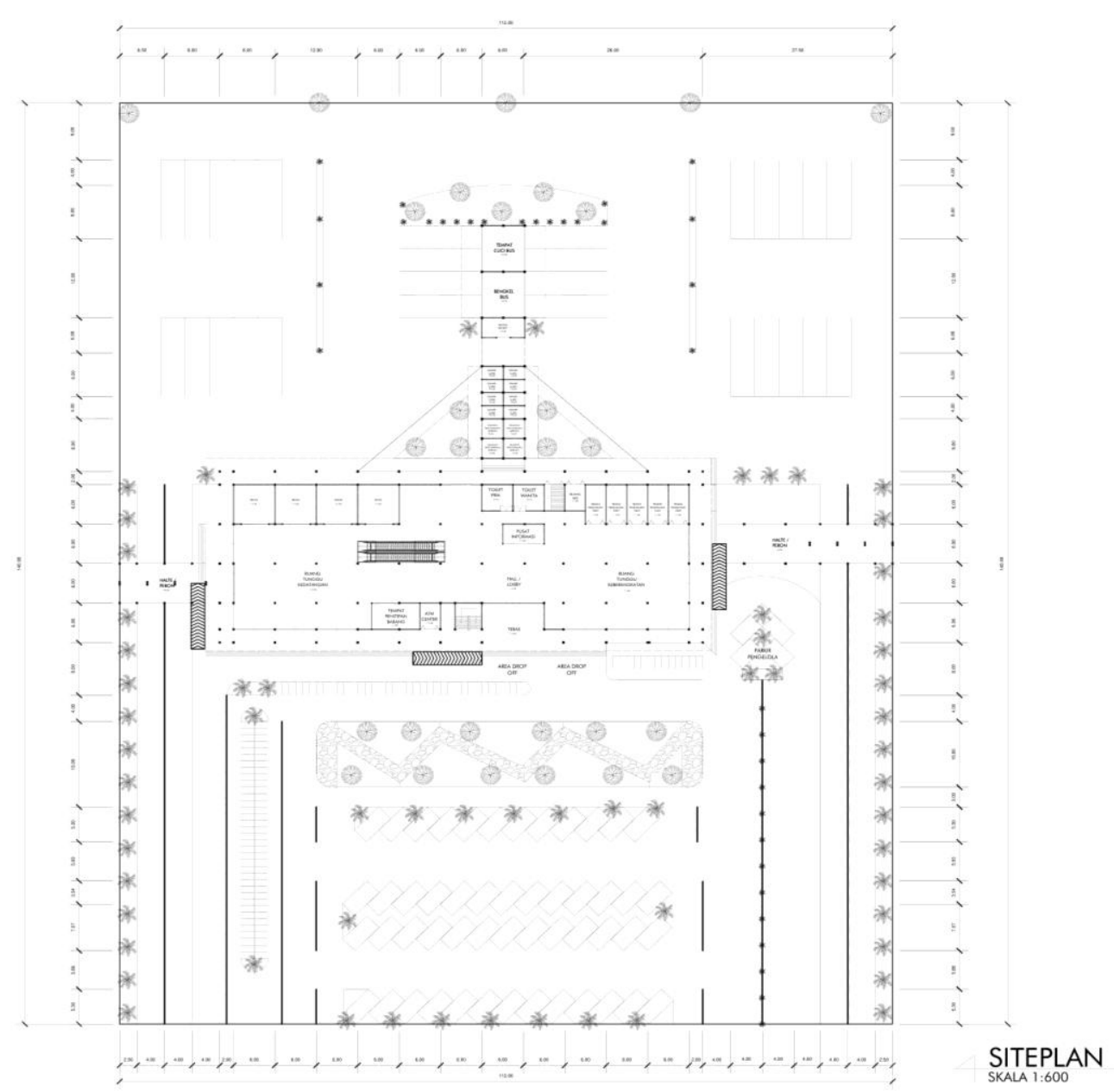

Gambar 10. Siteplan Terminal Bis Kedamin

Sumber: Penulis, 2020

Akses publik berfokus pada area depan bangunan terminal sesuai dengan zonasi. Akses ini berperan sebagai jalur kendaraan peruntukan pengunjung Terminal Bis. Akses privat berfokus hanya pada pelaku utama seperti pengunjung yang sudah siap berangkat. Kapasitas parkir sebanyak 20 parkir bus dan 120 parkir motor. Terdapat pula parkir mobil pada area depan kawasan yang berada di sisi timur site yaitu sebanyak 51 mobil. Elemen-elemen penyusun landscape bangunan Terminal Bis Kedamin terdiri dari bebatuan, tanaman hias, pola lantai, pencahayaan dan lain-lainnya. Suasana Redesain Terminal Bis Kedamin dapat dilihat pada gambar. 


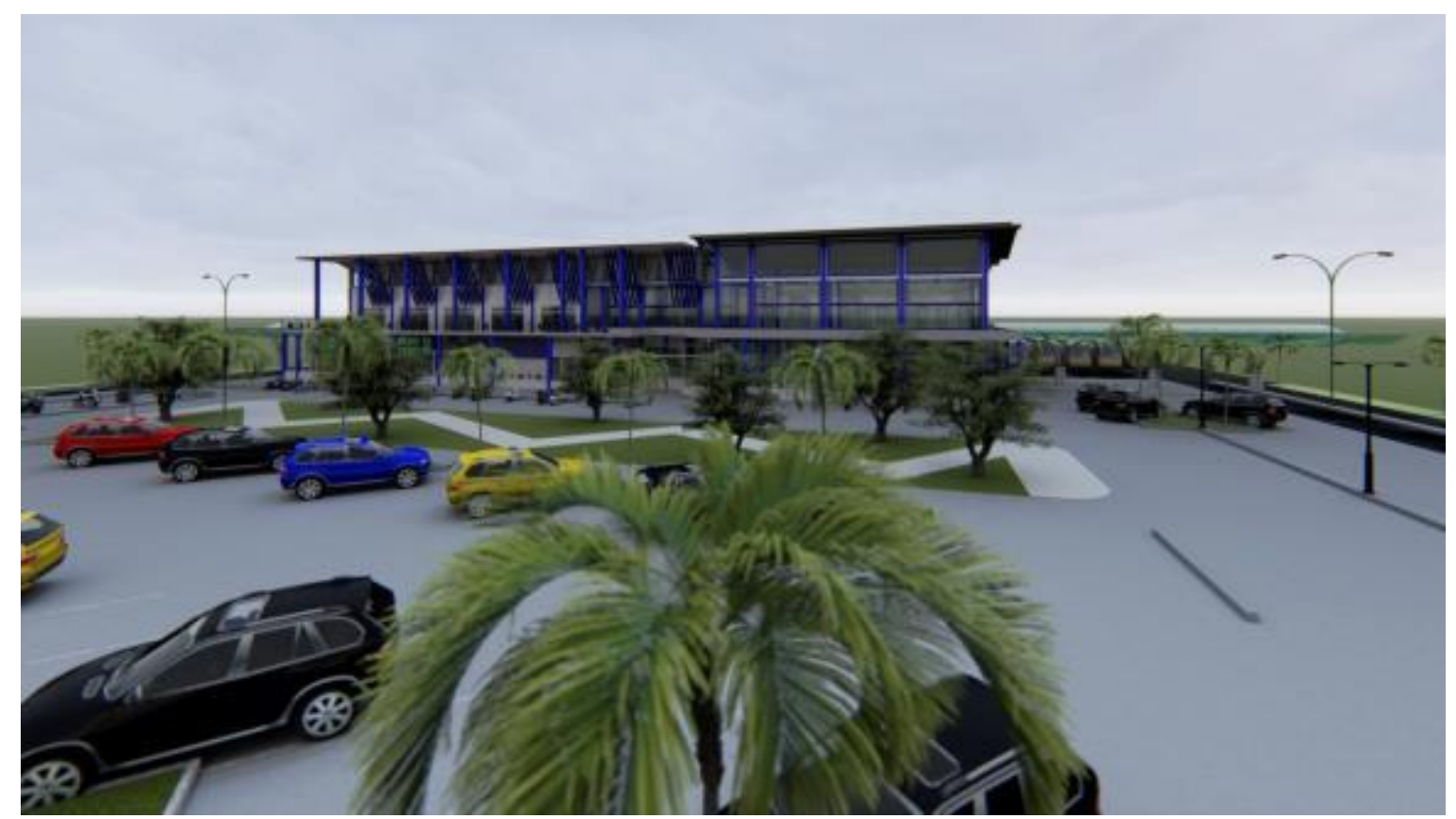

Gambar 11. Suasana Kawasan

Sumber: Penulis, 2020

Gambar denah lantai satu bangunan terminal bis kedamin disusun oleh zona publik (lobby, pusat informasi, area pengunjung, retail), zona servis (toilet, tempat cuci bus, bengkel bus).

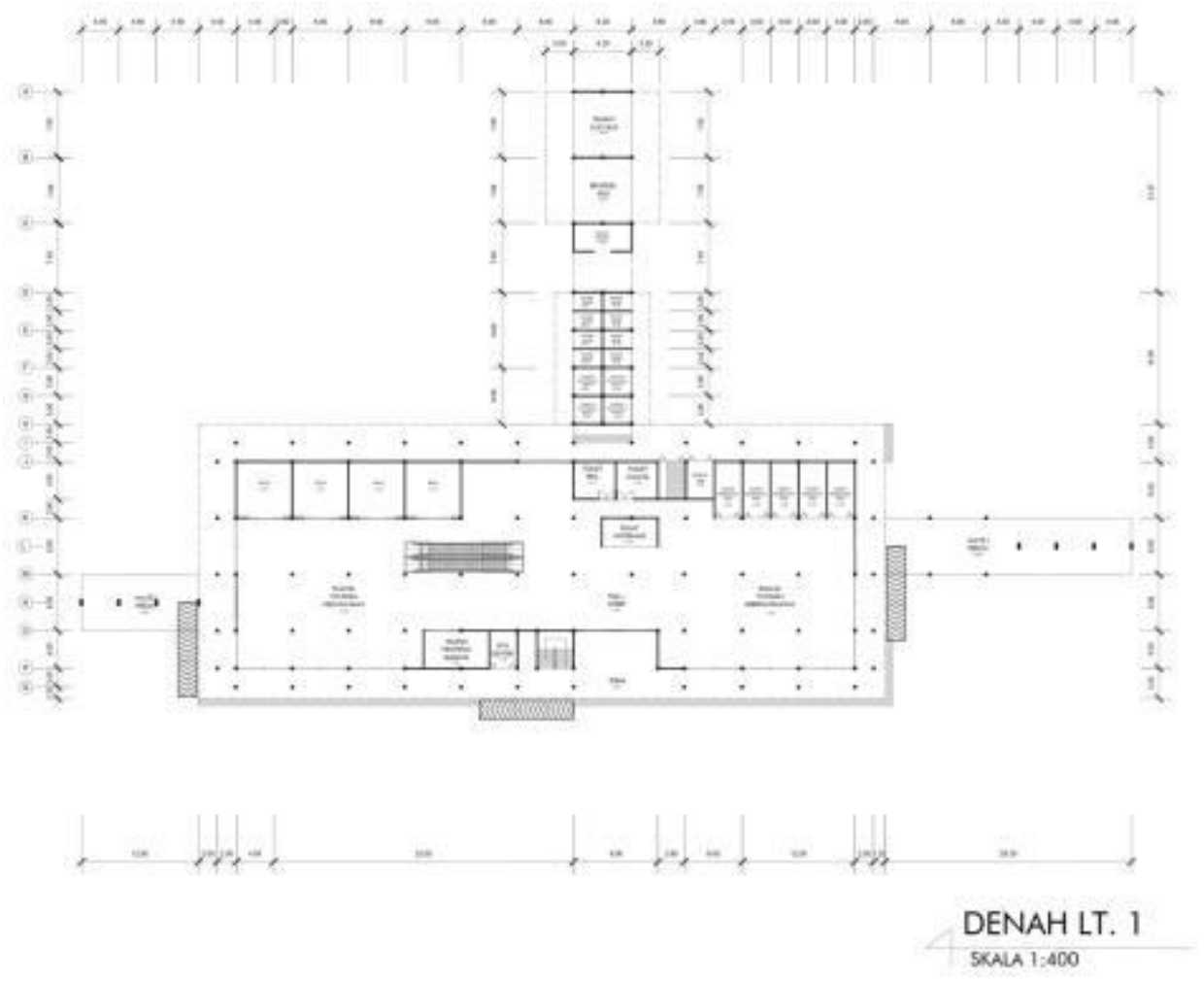

Gambar 12. Denah Lantai 1 Terminal Bis Kedamin Sumber: Penulis, 2020 
Gambar denah lantai dua bangunan terminal bis kedamin disusun oleh zona publik (retail, zona privat (ruang pengelola) dan zona servis (toilet).

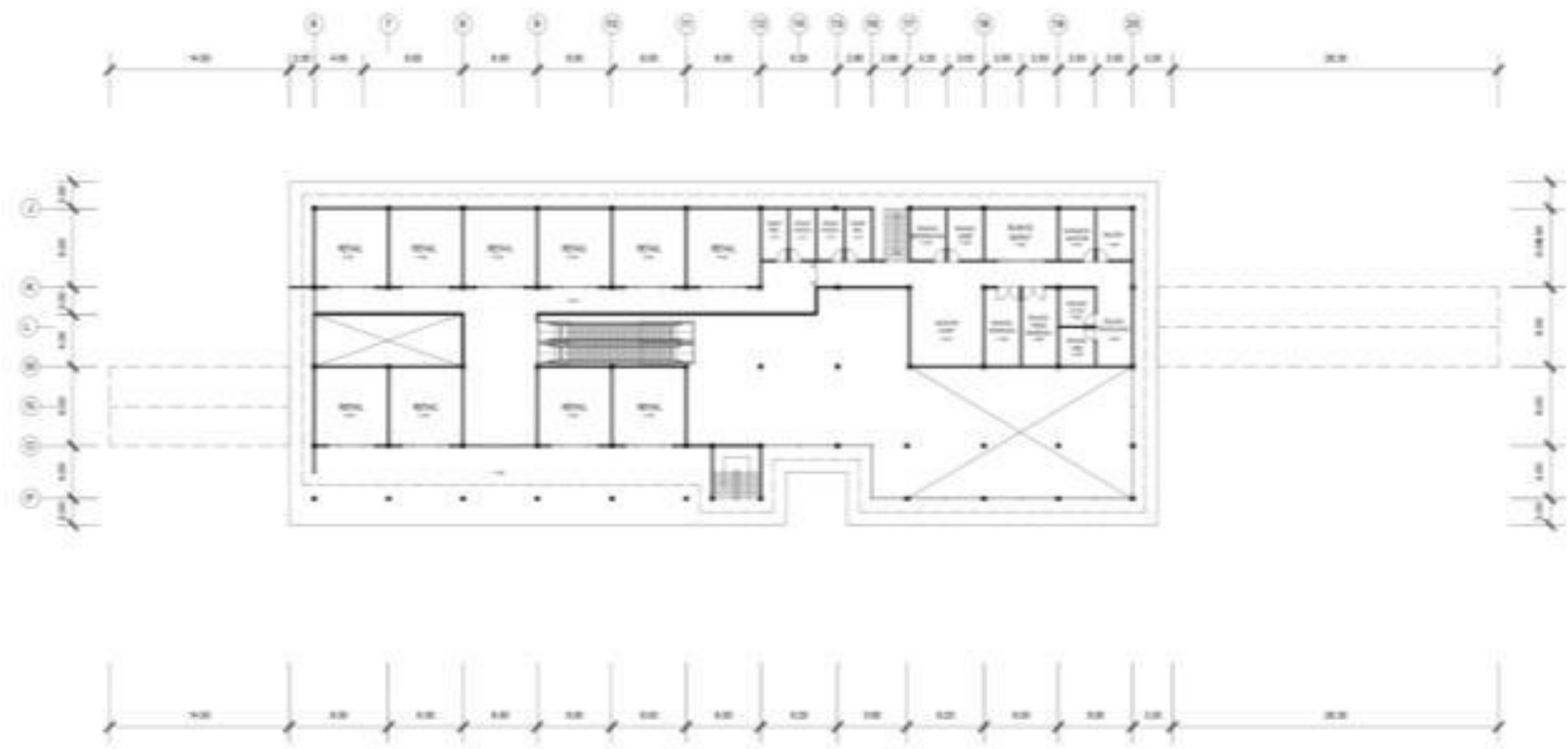

Gambar 13. Denah Lantai 2 Terminal Bis Kedamin

Sumber: Penulis, 2020

Perancangan Redesain Terminal Bis Kedamin merupakan kawasan pelayanan umum yang memiliki satu buah bangunan utama yang menerapkan unsur kontekstual antara bangunan dan lingkungan sekitarya. Permainan bentuk kaca dan secondary skin pada fasade bangunan untuk memunculkan kesan modern pada banguunan. Warna yang dominan yaitu warna biru dan putih yang merupakan warna netral untuk sebuah bangunan umum sehingga memberi kesan elegan dan modern. Massa utama berada di tengah site. Massa utama menggunakan atap dak beton untuk membentuk wujud yang harmonis dengan dengan kondisi bangunan sekitar.

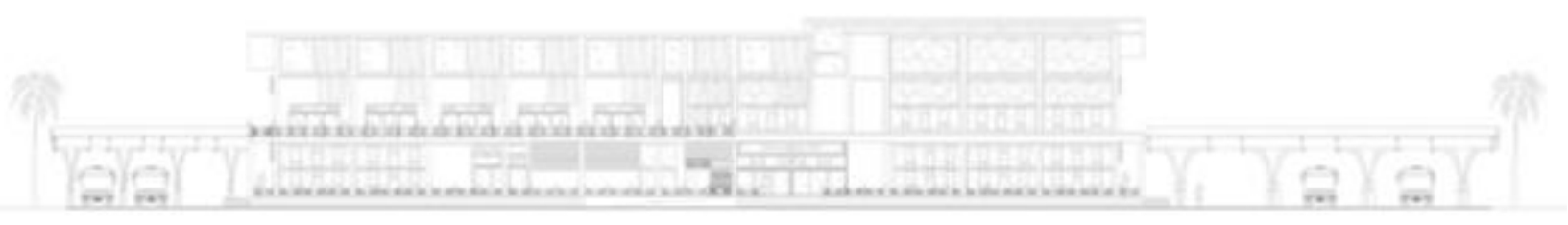

Gambar 14. Tampak Depan Terminal Bis Kedamin Sumber: Penulis, 2020

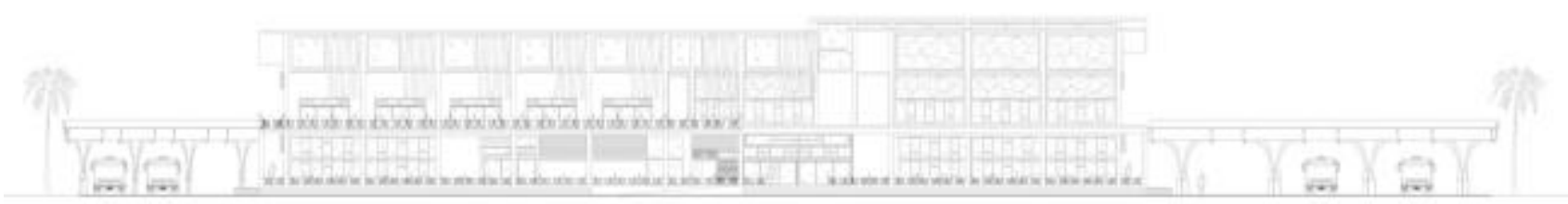

Gambar 15. Tampak Belakang Terminal Bis Kedamin Sumber: Penulis, 2020 
Tampak kanan kawasan menampakkan massa bangunan utama yang menggunakan bentuk atap setengah pelana untuk memaksimalkan cahaya matahari. Kaca bangunan menerapkan motif abstrak yang memunculkan kesan modern pada bangunan terminal. Pada bagian belakang merupakan area tunggu keberangkatan bus pengunjung. Dapat dilihat pada gambar.

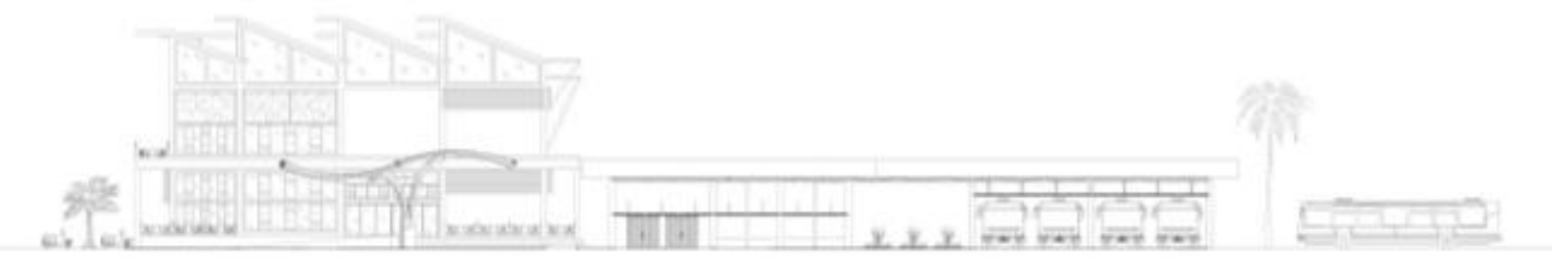

Gambar 16. Tampak Kanan Terminal Bis Kedamin

Sumber: Penulis, 2020

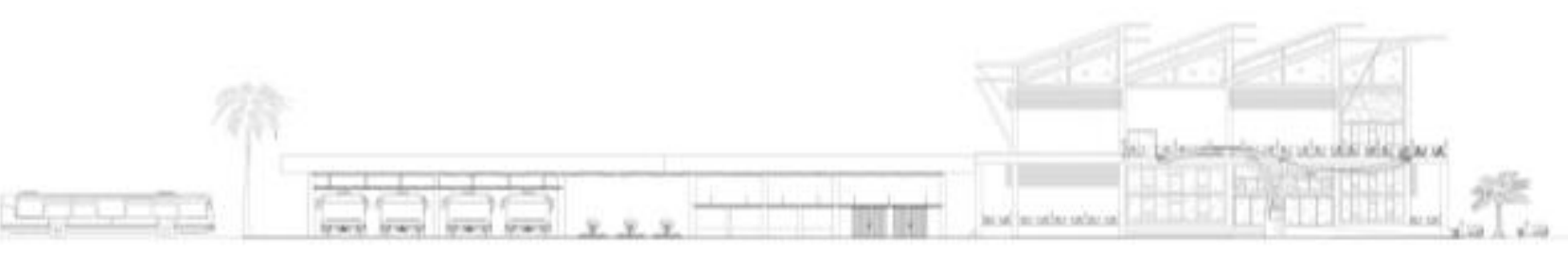

Gambar 17. Tampak Kiri Terminal Bis Kedamin

Sumber: Penulis, 2020

Perancangan Redesain Terminal Bis Kedamin merupakan kawasan pelayanan umum yang memiliki satu buah bangunan utama sehingga perancangan ini menggunakan 2 macam potongan arsitektural untuk menjelaskan baik secara struktural maupun tata ruang dalam beberapa massa. Dua macam potongan tersebut yaitu potongan $\mathrm{A}-\mathrm{A}$ dan potongan $\mathrm{B}-\mathrm{B}$.

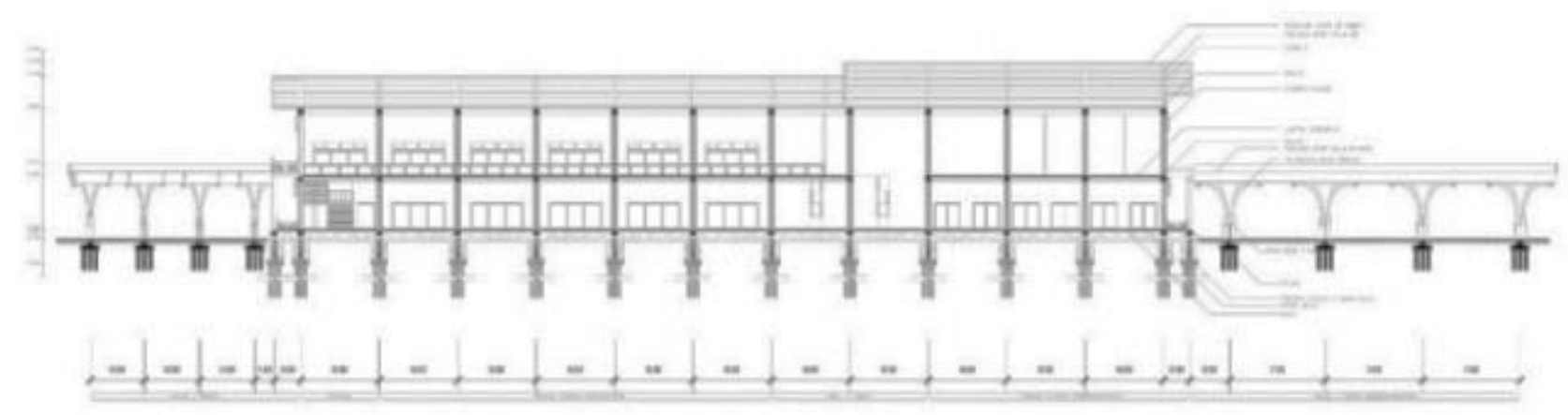

Gambar 18. Gambar Potongan A - A

Sumber: Penulis, 2020

Gambar potongan kawasan A-A memotong bangunan utama terminal. Pada potongan bangunan terminal menampakkan sifat ruang yang berbeda antar lantai. Potongan juga menampilkan struktur atap bangunan yang menggunakan baja WF pada bangunan utama dan pada bagian atap selasar menggunakan rangka atap baja ringan. Pondasi menggunakan minipile. 


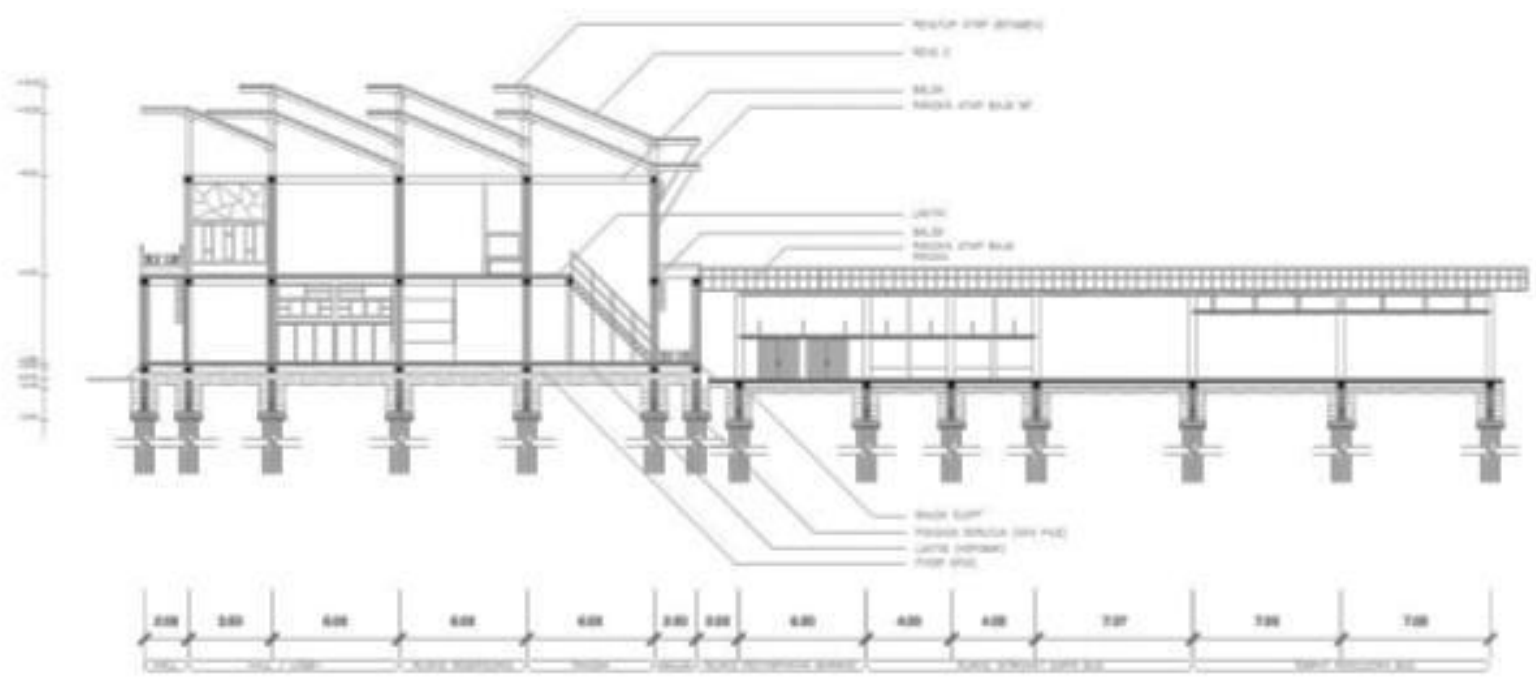

Gambar 19. Gambar Potongan B - B

Sumber: Penulis, 2020

Gambar potongan kawasan B-B memotong antara ruang tunggu kedatangan dan ruang tunggu keberangkatan. Rangka utama masing-masing gedung sama yaitu dari beton bertulang. Level lantai dan ketinggian yang terancang juga sama, yaitu 4 meter setiap lantai.

Terminal Bis Kedamin merupakan kawasan terminal yang masuk dalam pelayanan umum dengan konsep dinamis untuk menciptakan keseimbangan antara bangunan dan lingkungan. Gambaran visual suasana eksterior kawasan perancangan Redesain Terminal Bis Kedamin yang mewadahi sektor pelayanan umum dapat dilihat pada gambar

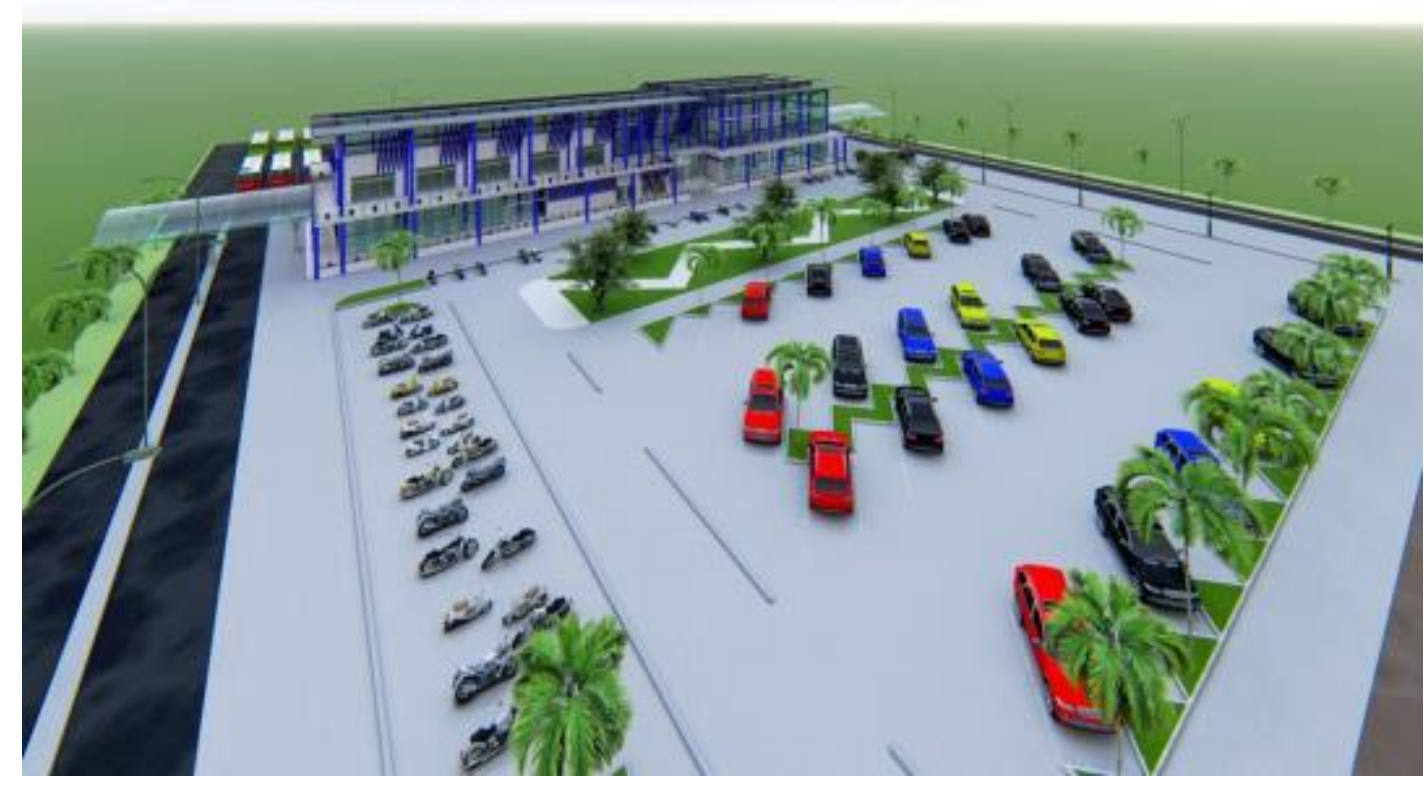

Gambar 20. Suasana Eksterior Terminal Bis Kedamin

Sumber: Penulis, 2020 
Sebagai mana fungsi Terminal Bis, haruslah menyediakan Ruang Tunggu untuk kedatangan penumpang, juga sebagai ruang tunggu keberangkatan penumpang. Ruang tunggu ini di buat terpisah agar aktifitas pada masing-masing kegiatan tidak terganggu.

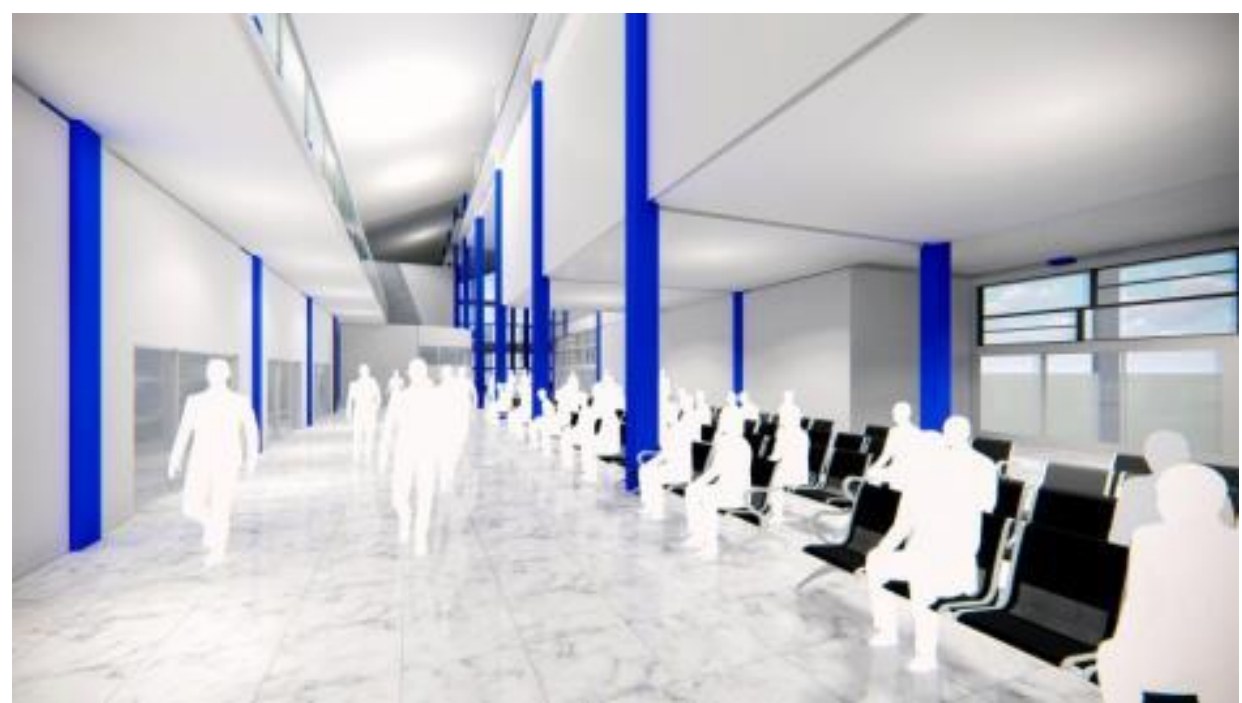

Gambar 21. Suasana Interior Ruang Tunggu Kedatangan Penumpang Terminal Bis Kedamin Sumber: Penulis, 2020

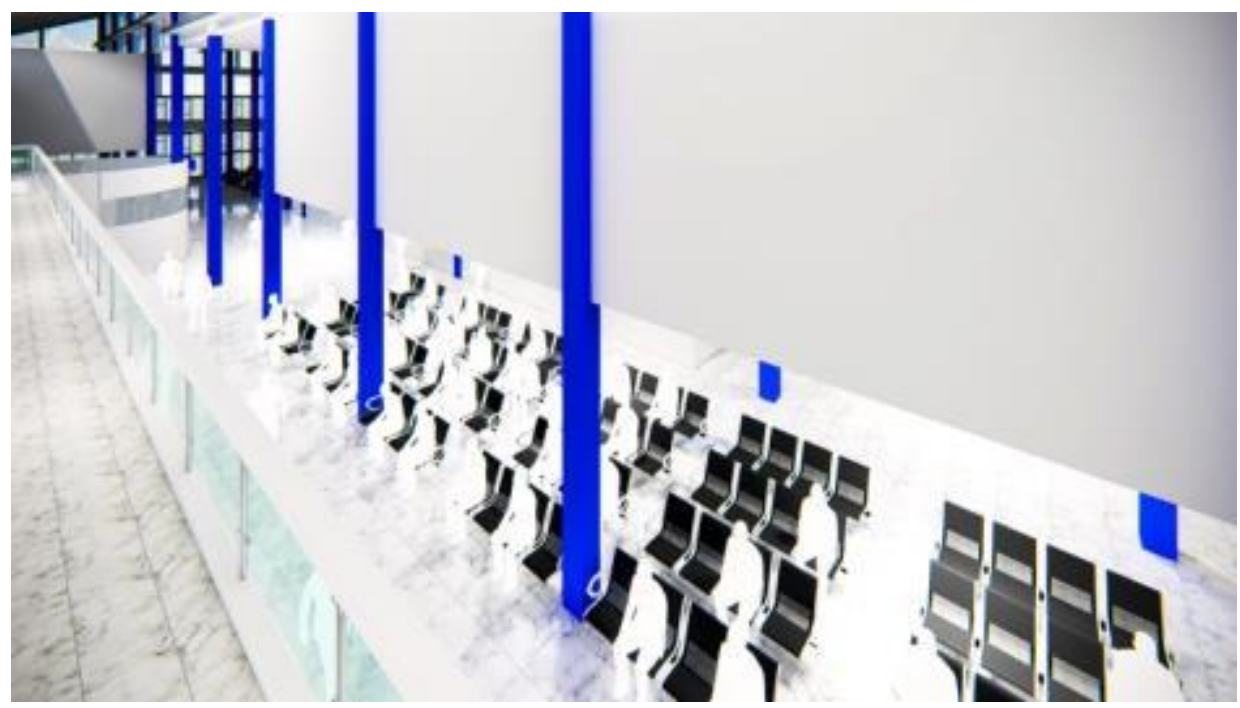

Gambar 22. Suasana Interior Ruang Tunggu Keberangkatan Penumpang Terminal Bis Kedamin Sumber: Penulis, 2020

Terminal Bis Kedamin memiliki fungsi pendukung berupa Retail - retail yang disewakan, selain sebagai fungsi pendukung bagi Terminal Retail-retail yang disewakan juga membantu pendapatan bagi penduduk setempat. 


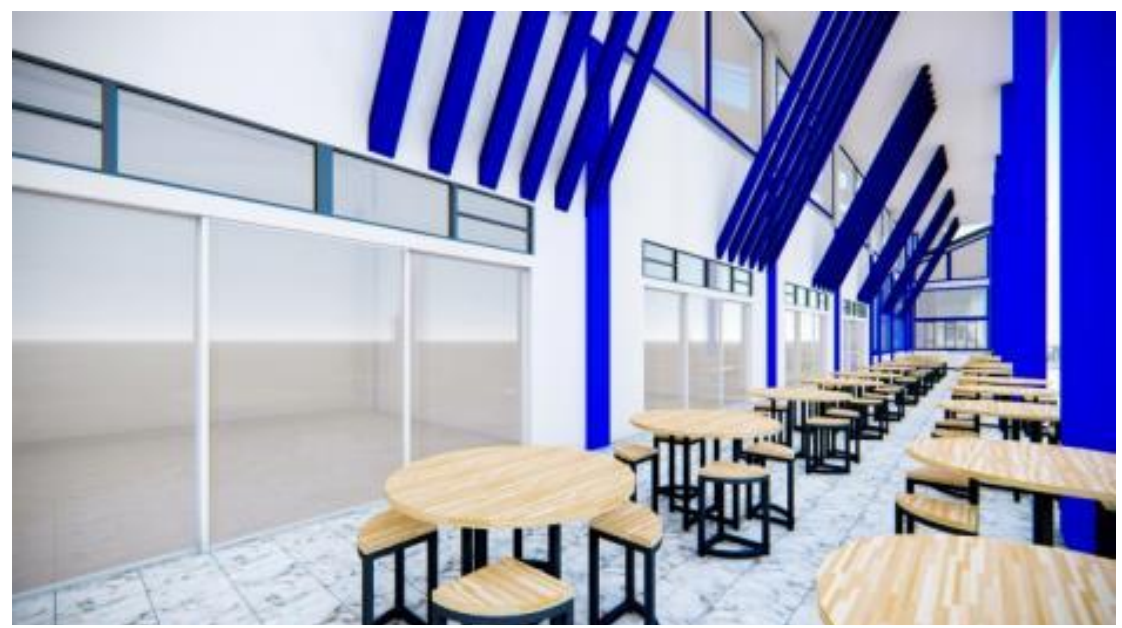

Gambar 23. Interior Retail Cafetaria Terminal Bis

Sumber: Penulis, 2020

\section{Kesimpulan}

Terminal Bis Kedamin Tipe B ini adalah prasarana untuk mendukung kegiatan transportasi yang ada di Kabupaten Kapuas Hulu dalam rangka untuk memperbaiki kualitas pelayanan serta kenyamanan bagi pelaku eksternal maupun pelaku internal. Pada sirkulasi Terminal Bis Kedamin dipisah antara area masuk dan keluar. Area masuk bus, mobil, dan sepeda motor juga dipisah agar tidak menimbulkan kemacetan. Terminal Bis ini dikelompokan berdasarkan PM 132 tahun 2015 sehingga persyaratan terpenuhi dan menciptakan keamanan dan kenyaman lebih bagi pengunjung dan pengelola. Pemisahan zona ruang juga dilakukan agar menghindari kemacetan sirkulasi baik luar maupun dalam bangunan, sehingga pengunjung bisa langsung menuju tujuannya baik itu yang datang ataupun yang ingin berangkat dari terminal. Redesain yang dilakukan guna mendukung dan memperbaiki kualitas Terminal pada saat ini sehingga lebih dapat digunakan secara maksimal. Fungsi pendukung yang ada pada terminal dapat membantu pendapatan daerah dan masyrakat setempat.

\section{Ucapan Terima Kasih}

Ucapan syukur kepada Tuhan Yang Maha Esa, kepada orang tua penulis, kepada para dosen pembimbing Proyek Tugas Akhir yaitu bapak Jawas Dwijo Putro, ST, MSc. selaku pembimbing utama dan bapak Muhammad Ridha Alhamdani, ST, MSc. selaku pembimbing pendamping yang telah memberikan kritik dan saran untuk penulis. Proyek Tugas Akhir ini, penulis mengucapkan rasa terima kasih yang sebesar-besarnya. Sebagai penutup penulis mohon maaf apa bila terdapat kesalahan dan kekhilafan dalam penulisan ini, semoga proyek tugas akhir ini bisa dipergunakan dan membantu banyak setiap pembacanya dan seluruh akademisi yang terkait.

\section{Daftar Acuan}

American Heritage Dictionary. (2000). The American Heritage Dictionary of English Language. Boston: Hougton Mifflin Harcourt

Kementerian Perhubungan Republik Indonesia. (1995). Keputusan Menteri Perhubungan RI No.13 Tahun 1995. Jakarta: Kementerian Perhubungan Republik Indonesia

Kementerian Perhubungan Republik Indonesia. (2015). Peraturan Menteri Perhubungan Republik Indonesia Nomor PM 132 Tahun 2015 tentang Penyelenggaraan Terminal Penumpang Angkutan Jalan. Jakarta: Kementerian Perhubungan Republik Indonesia

Morlok, E.K. (2005). Pengantar Teknik dan Perencanaan Transportasi. Jakarta: Erlangga

Pemerintah Daerah Kabupaten Kapuas Hulu. (2015). RPJMD Kabupaten Kapuas Hulu tahun 2015 tentang Gambaran Umum Kondisi Daerah. Kapuas Hulu: Pemerintah Daerah Kabupaten Kapuas Hulu

Warpani, S.P. (2002). Pengelolaan Lalu Lintas Dan Angkutan Jalan. Bandung: Institut Teknologi Bandung 